2. Bondarchuk, V. (2018). M. Gnatyuk and native opera performance (formation of personality). Kyivske muzykoznavstvo, [online] 57, pp. 201-211. Available at: https://kyivmusicology.com/index.php/journal/article/view/25/24 [Accessed 15 May 2019] [in Ukrainian].

3. Votrina, V. (2001). Art of singing and vocal technique of M. Donets-Tesseir. Kyiv [in Ukrainian].

4. Hnyd, B. (1997). History of vocal art. Kyiv: NMAU im. P. I. Chaykovskogo [in Ukrainian].

5. Kasyanenko, M. (2018). Life and creativity of Eugenia Miroshnichenko: source-study aspect. $\mathrm{PhD}$ thesis. Kharkiv National I. P. Kotlyarevsky University of Arts. Kharkiv [in Ukrainian].

6. Tsaruk, S. (2015). Implementation of the pedagogical principles of Alexander Mishuga in the work of M. Donets-Tesseir. Naukovi zbirky Lvivskoi natsionalnoi muzychnoi akademii im. M. V. Lysenka, 37, pp. 125-142 [in Ukrainian].

7. Shvachko, T. (2011). Singer and actress from God. Muzyka, 3, pp. 28-33 [in Ukrainian].

УДК 398.8(=161.2)

DOI: https://doi.org/10.33643/kmus.2019.58.19

\author{
Олена Серко, \\ аспірант кафедри музичної фольклористики \\ Львівської національної музичної академії ім. М. В. Лисенка, \\ викладач Рівненського музичного училища РДГУ \\ https://orcid.org/0000-0003-4361-2640 \\ len922@ukr.net \\ Olena Serko, \\ Postgraduate at the Department of Musical Folklore, \\ Lviv National Musical Academy named after Mykola Lysenko, \\ lecturer at Rivne Musical College \\ https://orcid.org/0000-0003-4361-2640 \\ len922@ukr.net
}

\title{
ЗБИРАЦЬКА СПАДЩИНА СТЕПАНА ТУРИКА
}

Публікацію присвячено дослідженню рукописів народних пісень, зібраних Степаном Туриком протягом 1912-1978 років. Актуальність обраної теми зумовлена тим, що в статті вивчаються невідомі архівні матеріали, що презентують народномузичний репертуар досі малодосліджених територій станом на середину XX століття. У запропонованій роботі вперше здійснено аналіз збирацької спадщини С. Турика.

Усю інформацію, що міститься в рукописах нотних зошитів, спочатку було систематизовано в таблиці Excel та проаналізовано. Це дало можливість зібрати певні відомості про збирацьку діяльність (дата, місце запису) та спадщину (жанри та коментарі до народних пісень) С. Турика, дані про інформантів, а також конкретизувати деякі факти з біографії дослідника. Додатки, вміщені в статті, значно доповнюють викладену інформацію. 
Ключові слова: Степан Турик, збирацька спадщина, зошит народних пісень.

Serko Olena. Collector's Heritage of Stepan Turyk. The publication is devoted to the study of manuscripts of notebooks of folk songs collected by folklorist-amateur Stepan Turyk during 1912-1978. These notebooks are stored in the Kremenets Regional Museum. The relevance of the chosen theme is conditioned due to the fact that folk songs, placed in notebooks, represent the traditional song repertoire of the second half of the twentieth century, respectively, are valuable assets for musical folklore as a science.

The purpose of the article is to determine the place and significance of the Stepan Turyk collection heritage for musical folklore and attract the attention of the researchers to his figure.

Methodology. All information contained in the manuscripts of notebooks was originally systematized in the Excel and analyzed. This made it possible to collect certain information about the collecting activities (date, place of record) and heritage (genres and comments on folk songs) S. Turyk, data about informants, and also to specify certain facts from the biography of the researcher. The appendices included in the article are greatly supplemented the provided information.

Main results and conclusions. The collector's work of amateur folklorist includes 29 note notebooks of songs, and this is 800 folk music pieces. There should be 29 of notebooks, but the numbers $13-16$ and 21 are missing, so 540 songs are available for analysis. Each notebook contains a different number of songs (from 1 to 60). The songs in the archive are placed predominantly in chronological order, having both sequential numbering and separately numbered on each notebook. In the collection folk musical works are arranged in order, according to «Note» have text and melody. The recording of musical texts complies with the norms of the school theory of music. Under the melody S. Turyk places the text of the song, divided into stanzas, so called «comments» (notes), information about the informant, as well as place and date of recording.

Among the songs collected by the researcher, the greatest share is made by ordinary works (household, romances, ballads, recruiting, chumaks, slavery, marching), quite a large number of wedding songs, as well as soup for dances and calendar ceremonial compositions - coldchana, vesnyanka, hayivka, Kupala, petrivchani and reaper songs. Also, Stepan Turyk recorded a singingduma about Oleksa Dovbush, which has 125 stanzas and is placed in the notebook number 28. Among folk works there are also songs of literary origin.

So, the collectible work of folklorist-amateur has considerable value for musical folklore as a science, especially nowadays when traditional song 
folklore is a thing of the past, and today it is unlikely that it is possible to repeat the recordings made by S. Turyk. Folk songs placed in notebooks are a valuable asset, representing the song repertoire of the second half of the twentieth century and can be involved in musical and folkloristic research.

Key words: Stepan Turyk, collector's heritage, folk songs notebook.

Серко Елена. Собирательское наследие Степана Турыка. Публикация посвящена исследованию рукописей народных песен, собранных фольклористом-любителем Степаном Турыком в течение 1912 1978 годов. Эти тетради хранятся в Кременецком краеведческом музее. Актуальность выбранной темы обусловлена тем, что в статье изучаются неизвестные архивные материалы, которые презентуют народномузыкальный репертуар до сих пор малоисследованных территорий по состоянию на середину XX века, и соответственно являются ценным приобретением для музыкальной фольклористики как науки.

Цель статьи - определение места и значения собирательского наследия Степана Турыка для музыкальной фольклористики и привлечение внимания исследователей к его личности.

Методология работы заключаетя в том, что вся информация, которая содержится в рукописях нотных тетрадей, сначала была систематизирована в таблице Excel и проанализирована. Это дало возможность собрать определенные сведения о собирательской деятельности (дата, место записи) и наследии (жанры и комментарии к народным песням) С. Турыка, данные об информантах, а также уточнить некоторые факты биографии исследователя. Приложения, помещенные в конце статьи, значительно дополняют изложенную информацию.

Главные результаты $\boldsymbol{u}$ выводы. Собирательское наследие фольклориста-любителя С. Турыка насчитывает 29 нотных тетрадей песен, а это 800 народных музыкальных произведений. Всего по номерам тетрадей должно было быть 29, но №№ 13-16 и № 21 отсутствуют, поэтому для анализа доступны 540 песен (согласно нумерации С. Турыка). В каждой тетради содержится разное количество песен (от 1 до 60). Песни в архиве размещены преимущественно в хронологическом порядке, имеют сквозную нумерацию, а также отдельно пронумерованы в каждой тетради. В сборнике народные музыкальные произведения размещены по порядку, в соответствии с «Ведомостью», имеют текст и мелодию. Запись музыкального текста соответствует нормам школьной теории музыки. Под мелодией С. Турык размещает текст песни, разделенный на строфы, т. н. «комментарии» (примечания), данные об информанте, а также место и дату записи. 
Среди песен, собранных исследователем, наибольшую часть составляют необрядные песни (бытовые, романсы, баллады, рекрутские, чумацкие, невольнические, маршевые), достаточно велико количество свадебных песен, также есть припевки к танцам и календарно-обрядовые произведения - колодчаные, веснянки, гаивки, купальские, петровские и дожиночные. Также Степан Турык записал песню-думу про Олексу Довбуша, которая имеет 125 строф и помещена в тетради № 28. Среди народных произведений встречаются песни литературного происхождения.

Итак, собирательское наследие фольклориста-любителя составляет значительную ценность для музыкальной фольклористики как науки, особенно сейчас, когда традиционный песенный фольклор уходит в прошлое и сегодня вряд ли есть возможность повторить записи, сделанные С. Турыком. Народные песни, собранные в тетрадях, являются ценными, представляют песенный репертуар второй половины $\mathrm{XX}$ века и могут использоваться в музыкально-фольклористических исследованиях.

Ключевые слова: Степан Турык, собирательское наследие, тетрадь народных песен.

Сьогодні українська музична фольклористика досить потужно розвивається як наука. Поряд із структурно-типологічним напрямом, що займається вивченням традиційних народних наспівів (їх типів, форм, ареалів побутування), розвивається також історіографічний напрям, що займається дослідженням збирацької та наукової діяльності як видатних вчених, так і фольклористів-аматорів, які 3 ентузіазмом займалися збиранням українських народних пісень.

Степан Іванович Турик - один з фольклористів-любителів, що збирав фольклор в основному в межах Тернопільської області та в с. Липа Дубенського району Рівненської області, принагідно роблячи поодинокі записи в інших регіонах України.

Частина його збирацького спадку була опублікована [3] та частково вивчалася етномузикологами [7] та філологами ${ }^{1}[8,9]$. Однак, не зважаючи зважаючи на поодинокі публікації, його рукописний архів досі залишається практично недослідженим. Народні пісні, зібрані С. Туриком, є предметом цього дослідження. Актуальність обраної теми також обумовлена тим, що його записи репрезентують пісенний репертуар другої половини XX століття, - час, коли традиційна музика побутувала досить

\footnotetext{
${ }^{1}$ Побутові пісні та балади досліджувала учениця Кременецького ліцею ім. Уласа Самчука Анастасія Стасів під керівництвом вчителя української мови та літератури цього ліцею Трачук Віри Миколаївни.
} 
активно. У пропонованій роботі вперше будуть проаналізовані нотні збірки народних музичних творів з неопублікованої архівної спадщини фольклориста-аматора С. Турика, що становить наукову новизну.

Виходячи 3 вищесказаного, мета статті - визначення місця та значення збирацької спадщини Степана Турика для музичної фольклористики та привернення уваги дослідників до його постаті. Мета роботи реалізується через конкретні завдання - аналіз та опис нотних зошитів рукопису, а також пісень, що вміщені в них. Методологія роботи полягає в тому, що уся інформація, яка міститься в збирацькому архіві, спочатку була оформлена в таблиці Excel, систематизована та проаналізована. Це дало можливість зібрати певні відомості про збирацьку діяльність (дата, місце запису) та спадщину (жанри та коментарі до народних пісень) С. Турика, дані про інформантів, а також конкретизувати деякі факти з біографії дослідника. Додатки, вміщені в кінці статті, конкретизують та доповнюють викладену інформацію.

$* * *$

Степан Іванович Турик - український філолог, педагог, фольклористаматор, письменник.

Інформації про життєвий шлях Степана Турика вкрай мало. Відомо хіба кілька біографічних фактів. Турик С. I. народився 24 грудня 1892 року (за новим стилем 5 січня 1893 року [ 10, с. 477]) у с. Шкроботівка, що на Тернопільщині ${ }^{1}$, навчався на Вищих педагогічних курсах при Київському Університеті (1919), вже у зрілому віці закінчив філологічний факультет Кременецького педагогічного університету ${ }^{2}$, a також був вчителем на Чернігівщині. Брав участь у Першій світовій війні, мав звання прапорщика. 31917 року - голова ревкому в с. Жванець ${ }^{3}$. Після 1920 року займався педагогічною діяльністю в селах рідної Шумщини, а також в с. Уховецьк ${ }^{4}$ (1938). Від вересня 1939 року Степан Іванович працював у Кременці. У період 1944-1948 років був інспектором шкіл Кременецького району, а з 1948 - вчитель і завуч СШ № 2 м. Кременця. Згодом вчителював у СШ № 1 [10, с. 477].

Степан Іванович все життя займався педагогічною діяльністю, але поряд із цим, збирав український пісенний фольклор. Збирацький доробок цього фольклориста-аматора налічує 800 творів, що вміщені у 29 нотних зошитах. Існує два рукописних примірники цих зошитів: один зберігається

\footnotetext{
${ }^{1}$ Шкроботівка - село Шумського району Тернопільської області, центр сільради.

${ }^{2}$ Нині - Кременецький обласний гуманітарно-педагогічний інститут імені Тараса Шевченка.

${ }^{3}$ Сьогодні це село належить до Кам'янець-Подільського району Хмельницької області.

${ }^{4}$ Нині Ковельського району Волинської області.
} 
в ІМФЕ НАНУ, інший - у Кременецькому краєзнавчому музеї. У липні 2018 року авторкою було здійснено поїздку в архівний фонд музею м. Кременця. Віднайдені матеріали було докладно проаналізовано.

На даний момент в архіві Степана Турика зберігається 24 пронумерованих нотних зошити, в яких міститься 540 пісень, крім цього зошит «Весілля на Дубенщині» (240 пісень), зошит 3 поясненнями до деяких народних творів, друкований текст обряду «Читання корони», трудова книжка, а також роман-хроніка в 3-х частинах «Крізь бурі і громи до кращого завтра».

Найбільше зацікавлення в мене викликали нотні зошити. Всього за номерами зошитів мало би бути 29, проте № 13-16 та № 21 відсутні. У кожному зошиті міститься різна кількість пісень ${ }^{1}$. У зошитах № 8-11, 17-20, 22, 25-27 та 29 вміщується по 20 пісень. Наприклад, зошит № 3 складається всього 3 однієї пісні. Це сербська пісня «Лєпа Мара». У зошиті № 28 знаходиться теж один твір - співанка-дума про Олексу Довбуша. Записувач вирішив розділити іiі за змістом на 20 пісень (віршів), що виконуються на одну мелодію. Відповідно, згідно з нумерацією Степана Турика, у зошиті № 28 є 20 пісень, № 761-780. Найбільше народномузичних творів міститься у зошитах № 1 (50 пісень) та № 12 (60 творів).

3 напису на зошиті «Весілля на Дубенщині» відомо, що в зошитах № 13-14 міститься 130 пісень, зошиті № 15 - 40 та № 16 - 70 творів. Разом у зошитах № 13-16 знаходиться 240 зразків народної музичної творчості. Очевидно, що ці пісні були продубльовані окремою збіркою «Весілля на Дубенщині». 2001 року під однойменною назвою матеріали «Весілля» (170 пісень, що вміщені у зошитах № 13-15) були опубліковані в м. Кременці [3].

Степан Турик був старанним упорядником свого архіву. Пісні в нотних зошитах розміщені в хронологічному порядку їх записів ${ }^{2}$, мають як наскрізну нумерацію, так і окремо по кожному зошиту. Всього у 29 нотних збірках налічується 800 пісень. На початку кожного зошита є таблиця, яку С. Турик називав «Відомість про українські народні пісні». У цій «Відомості» містяться такі дані: номер пісні в зошиті, номер в наскрізній нумерації, назва, жанр, коротка характеристика / зміст (або примітки) пісні, місце та дата запису, сторінка. Зошити № 12, 17-19 не мають такої «Відомості», а починаючи 3 зошита № 20 вказувалися ще й ПІБ інформанта. У зошитах № 12 і № 17 відсутні «Відомості», бо пісні записані в одному селі, а в першому - ще й від однієї інформантки.

\footnotetext{
1 Зміст зошитів відображено у додатку № 1 .

2 Крім пісень, що вміщені у зошиті № 1 .
} 
У четвертій колонці таких початкових таблиць, що мала назву «Характеристика (характер) / зміст пісні», переважно вказувався ще й жанр твору. «Характеристика» могла обмежуватися всього одним словом, яке вказувало на жанр пісні (наприклад, як у пісні № 2 із зошита № 1 «чумацька»), а могла бути досить розлогою (наприклад, як у пісні № 11 (641) із зошита № 22 - «Балада про свекруху й невістку. Свекруха зразу не злюбила невістки, прокляла іiі, щоб деревом стала. Коли вернувся син із солдатів, то намовляла його зрубати деревце, а воно «деревце» стало промовляти. Розпач сина...»).

Після «Відомостей» у кожній збірці вміщені народні музичні твори за порядком. Збирач народної творчості записував текст та мелодію пісні. У першому зошиті всі мелодії були гармонізовані С. Туриком для чотириголосного хору. У збірках № 2-4 мелодії подані у дво- чи триголоссі. Очевидно, це пов'язано 3 практикою тих років видавати народні пісні, розкладені на кілька голосів. Починаючи 3 п'ятого зошита мелодії, в основному, одноголосні. Музичний текст пісень записаний в простих академічних розмірах, в різних тональностях, має вказівку на темп та динамічні відтінки. Іноді використовувалися акцентні позначки. У цілому, запис мелодій відповідає нормам шкільної теорії музики. Зустрічаються випадки, коли пісні, що виконувалися на одну мелодію, збирач народної творчості записував під одним номером, додаючи нумерацію до тексту, яка вказувала, що то різні твори. Натомість співанкадума про Олексу Довбуша (вміщена у зошиті № 28) має 20 строф, кожна 3 яких має окремий номер. Таким чином, згідно з нумерацією С. Турика $\epsilon$ 540 одиниць народних музичних зразків. Згідно з нашою нумерацією (твори, що мають кілька варіантів тексту рахуємо як різні, а співанку-думу вважаємо цілісною) є також 540 пісень та співанка-дума, загалом 541 твір.

Нижче, під мелодією, С. Турик розміщує текст пісні, поділений на строфи, а також т зв. «коментарі» (примітки). В примітках до пісні записувач дає пояснення діалектних чи невідомих слів, вказує, які дії повинні виконувати учасники обряду (якщо це обрядова пісня ${ }^{1}$ ). Досить часто С. Турик порівнює музичні твори за змістом чи мелодією. Деякі пісні супроводжуються роздумами про походження пісні, а також містять інформацію про обставини запису. 3 коментарів також дізнаємося, що у 1913-1914 навчальному році С. Турик учителював в м. Нові Млини Сосницького повіту ${ }^{2}$, що на Чернігівщині ${ }^{1}$.

\footnotetext{
${ }^{1}$ Також є вказівки які рухи виконувати під час співу гаївок, що вміщені у зошиті № 1 .

${ }^{2}$ Нині це с. Нові Млини Борознянського району Чернігівської області, належить до Височанської сільської громади.
} 
Після тексту та «коментарів» вказано місце та дату запису, а також прізвище, ім'я, по-батькові та рік народження співака. Рідше зустрічаються дані про освіту чи місце праці інформанта.

Як свідчать паспортні дані пісень, перший запис було здійснено 1912 року. На той момент С. Турику було всього 19 років. Це пісня «При дорозі стоїть пень» була записана в рідному селі збирача від Зеленської Славки та вміщена у дев'ятому зошиті під № 2. У примітках вказано, що «запис знайшовся у 1966 році». Упродовж 1912-1924 рр. С. Туриком було записано 43 народних зразки, а 1930 року - всього одну пісню. Очевидно, що ці записи були принагідними та, здебільшого, поодинокими, проте деякі з них фіксувалися під час обрядовій ${ }^{2}$, що, безумовно, становить певну цінність. Далі після 30-літньої перерви С. Турик відновив свою збирацьку діяльність. У період з 1960 до 1978 року було зафіксовано 497 народних музичних творів. Найбільша кількість пісень зібрана 1967 року - аж 80. Дані про кількість пісень та рік їх запису вміщено у Додатку 2.

Степан Турик в основному збирав фольклор в усіх районах Тернопільської області. Найбільшу кількість пісень - 134 зразки зафіксовано у рідному селі Шкроботівка. Значно менше є записів 3 с. Биківці (43), с. Малі Дедеркали (33) та с. Шумбар (17), що належать до Шумського району, м. Кременця (43), с. Млинівці (33) Кременецького району, с. Погрібці (18) Зборівського району Тернопільської області. Більше 40 одиниць записано в с. Нова Котельня Андрушівського району Житомирської області. Зрештою, зовсім мало записів - переважно по 1-2, рідше по 8-13 зразків - зібрано у населених пунктах Тернопільської, Рівненської та Волинської областей, Вінниччини, Хмельниччини, Київщини та навіть у м. Скадовську (Херсонська область) ${ }^{3}$.

С. Турик іноді записував народні пісні від людей, що тимчасово перебували в Тернопільському краї. При таких обставинах він обов'язково вказував, звідки походить пісня (або звідки родом інформант, інколи - в яких ще населених пунктах вона побутувала), також вказуючи цей населений пункт у «Відомості». Скажімо, лірична пісня «Шуміла дуброва» (зошит № 1 / 42) була записана в Кременці від Герца Миколи Івановича, студента Кременецького ДПІ, родом із с. Лохово Мукачівського району

\footnotetext{
${ }^{1}$ У біографічних відомостях вказано лише, що С. Турик «вчителював на Чернігівщині» [10, с. 477], а «коментарі» рукопису вказують точне місце та час перебування.

2 Як от пісні весняного циклу (вміщені у зошиті № 1) були зафіксовані весною 1920 року на сільській площі, де співали хлопці і дівчата.

${ }^{3}$ Повний перелік областей та кількість творів, записаних в них вміщено у додатку 3.
} 
Закарпатської області. Географічна інформація вказана також й у паспорті пісні, оскільки це місце її походження.

У архіві збирача $є$ дві народні пісні, що мають неукраїнське походження. Перша 3 них - «Лєпа Мара» (зошит № 3 / 1) - зафіксована у 1915 році від полоненого серба з Боснії. В примітках до твору вказано, що С. Турик співав iï багато разів із сербами. Імовірно, що запис був зроблений під час Першої світової війни, коли збирач був у війську. Друга ж - «Дуб на дуба похилився» (зошит № 1 / 39) - записана в м. Кременець від старенького дідуся, переселенця 3 м. Тарноград Білгорайського повіту Люблінського воєводства. У примітках фольклорист-любитель аналізує текст та ритм пісні, говорить про «вплив польської мови на говірку холмщаків».

Серед пісень, зібраних дослідником, найбільшу частку становлять звичайні твори (побутові, романси, балади, рекрутські, чумацькі, невільницькі, маршові), досить велика кількість весільних пісень, також $\epsilon$ приспівки до танців та календарно-обрядові твори - колодчані, веснянки, гаївки, купальські, петрівчані та обжинкові. Також Степан Турик записав співанку-думу. Серед народних творів зустрічаються також пісні літературного походження. Всього С. Туриком зафіксовано більше сотні обрядових творів. Жанри пісень подаємо згідно з зазначеними дослідником:

- 70 весільних пісень, 60 з яких зафіксовані від однієї інформантки в рідному с. Шкроботівка;

- 19 творів, жанри яких визначені як веснянка, гра зі співом, та гаївка ${ }^{1}$, 12 з яких з с. Шкроботівка;

- 8 купальсько-петрівських зразків, знову ж таки з с. Шкроботівка;

- 4 твори, що належать до жнивних обрядів (1 дожинкова, 3 обжинкові);

- 6 колискових;

- 2 жартівливі колядки;

- 2 колодчані;

- 38 творів належать до приспівок до танцю.

Деякі з записів С. Турика вже були опубліковані у збірниках: «Весільні пісні» (1982) [4; 5], «Балади» (1988) [2], «Пісні Тернопільщини» (1989) [6] та «Весілля на Дубенщині» (2001) [3].

Варто зазначити, що при укладанні архіву С. Турик позиціонував себе як учитель-пенсіонер. Про це він вказував чи не після кожної пісні «Записав учитель-пенсіонер Стеран Турик» [1, зош. № 17/ с. 2]. Впорядкувавши кожен нотний зошит, він відсилав їх до Інституту

\footnotetext{
${ }^{1}$ У дійсності ж «гаївки» (три зразка) за жанровим визначенням С. Турика належать до купальсько-петрівського жанрового циклу.
} 
мистецтвознавства, фольклору та етнографії ім. М. Рильського 3 супровідними листами. У листах він завжди просив повідомляти його про одержання цих зошитів та висловлювати свої думки як стосовно самих пісень, так і стосовно т. зв. «коментарів». Це свідчить про те, що С. Турик уважно ставився до духовної української спадщини та ревно любив свій рідний край. Він намагався докладно описати події, що тут відбувалися ${ }^{1}$.

С. Турик був фольклористом-аматором і за покликом душі збирав народні пісні для збереження традицій свого краю. I йому це дійсно вдалося: його збирацький доробок становить значну цінність для музичної фольклористики як науки, особливо зараз, коли традиційний пісенний фольклор відходить у минуле, і сьогодні навряд чи є можливість повторити записи, зроблені С. Туриком. Отож, його збирацька спадщина є вагомим внеском у музичну фольклористику. Народні пісні, що вміщені в зошитах, $\epsilon$ цінним надбанням, що репрезентує традиційний пісенний репертуар другої половини $\mathrm{XX}$ століття та може залучатися до музичнофольклористичних досліджень.

Додаток № 1

\begin{tabular}{|c|c|c|c|c|c|}
\hline № зошита & $\begin{array}{c}\text { Кількість } \\
\text { пісень }\end{array}$ & № зошита & $\begin{array}{c}\text { Кількість } \\
\text { пісень }\end{array}$ & № 3ошита & $\begin{array}{c}\text { Кількість } \\
\text { пісень }\end{array}$ \\
\hline $\mathbf{1}$ & 50 & $\mathbf{9}$ & 20 & $\mathbf{2 2}$ & 20 \\
\hline $\mathbf{2}$ & 15 & $\mathbf{1 0}$ & 20 & $\mathbf{2 3}$ & 25 \\
\hline $\mathbf{3}$ & 1 & $\mathbf{1 1}$ & 20 & $\mathbf{2 4}$ & 25 \\
\hline $\mathbf{4}$ & 10 & $\mathbf{1 2}$ & 60 & $\mathbf{2 5}$ & 20 \\
\hline $\mathbf{5}$ & 16 & $\mathbf{1 7}$ & 20 & $\mathbf{2 6}$ & 20 \\
\hline $\mathbf{6}$ & 23 & $\mathbf{1 8}$ & 20 & $\mathbf{2 7}$ & 20 \\
\hline $\mathbf{7}$ & 35 & $\mathbf{1 9}$ & 20 & $\mathbf{2 8}$ & 1 \\
\hline $\mathbf{8}$ & 20 & $\mathbf{2 0}$ & 20 & $\mathbf{2 9}$ & 20 \\
\hline
\end{tabular}

Додаток № 2

\begin{tabular}{|c|c|c|c|c|c|}
\hline Рік запису & $\begin{array}{c}\text { Кількість } \\
\text { пісень }\end{array}$ & Рік запису & $\begin{array}{c}\text { Кількість } \\
\text { пісень }\end{array}$ & Рік запису & $\begin{array}{c}\text { Кількість } \\
\text { пісень }\end{array}$ \\
\hline $\mathbf{1 9 1 2}$ & 1 & $\mathbf{1 9 2 4}$ & 1 & $\mathbf{1 9 6 9}$ & 40 \\
\hline $\mathbf{1 9 1 3}$ & 2 & $\mathbf{1 9 3 0}$ & 1 & $\mathbf{1 9 7 0}$ & 40 \\
\hline $\mathbf{1 9 1 4}$ & 12 & $\mathbf{1 9 6 0}$ & 1 & $\mathbf{1 9 7 2}$ & 20 \\
\hline $\mathbf{1 9 1 5}$ & 8 & $\mathbf{1 9 6 1}$ & 35 & $\mathbf{1 9 7 3}$ & 25 \\
\hline $\mathbf{1 9 1 6}$ & 1 & $\mathbf{1 9 6 2}$ & 28 & $\mathbf{1 9 7 4}$ & 25 \\
\hline $\mathbf{1 9 2 0}$ & 5 & $\mathbf{1 9 6 3}$ & 24 & $\mathbf{1 9 7 5}$ & 20 \\
\hline $\mathbf{1 9 2 1}$ & 8 & $\mathbf{1 9 6 4}$ & 59 & $\mathbf{1 9 7 6}$ & 20 \\
\hline $\mathbf{1 9 2 2}$ & 3 & $\mathbf{1 9 6 6}$ & 39 & $\mathbf{1 9 7 7}$ & 21 \\
\hline $\mathbf{1 9 2 3}$ & 2 & $\mathbf{1 9 6 7}$ & 80 & $\mathbf{1 9 7 8}$ & 20 \\
\hline
\end{tabular}

\footnotetext{
${ }^{1}$ Про це свідчать три томи роману-хроніки «Крізь бурі і громи до кращого завтра».
} 
Додаток № 3

\begin{tabular}{|l|c|}
\hline Область (к-сть населених пунктів) & Кількість зразків \\
\hline Тернопільська область (44) & 462 \\
\hline Житомирська область (1) & 45 \\
\hline Рівненська область (2) & 11 \\
\hline Хмельницька область (6) & 3 \\
\hline Львівська область (2) & 3 \\
\hline Волинська область (1) & 2 \\
\hline Чернігівська область (1) & 1 \\
\hline Вінницька область (1) & 1 \\
\hline Київська область (1) & 1 \\
\hline Закарпатська область (1) & 1 \\
\hline Херсонська область (1) & 1 \\
\hline Люблінське воєводство (1) & 1 \\
\hline Боснія (1) & \\
\hline
\end{tabular}

1. Архівні матеріали із фондів Кременецького краєзнавчого музею (ККМ). Од. зб. 8604-9325. Група фольклор. Од. зб. 1-742.

2. Балади : родинно-побутові стосунки / упоряд. О. Дей, А. Ясенчук. Київ : Наукова думка, 1988. 528 с.

3. Весілля на Дубенщині: 170 українських весільних пісень, записаних учителемпенсіонером Туриком Степаном Івановичем / упор. М. Якубчук. Кременець, 2001. 86 с.

4. Весільні пісні : у 2 т. Т. 1 / упор. М. М. Шубравська. Київ : Наукова думка, 1982. 870 с.

5. Весільні пісні : у 2 т. Т. 2 / упор. М. М. Шубравська. Київ : Наукова думка, 1982. 679 с.

6. Пісні Тернопільщини: календарно-обрядова та родинно-побутова лірика : пісенник. Вип. 1 / упор. С. І. Стельмащук, П. К. Медведик. Київ : Музична Україна, 1989. 496 с.

7. Смоляк О. Ладканкові типи весільних пісень Південної Волині (на матеріалі с. Липа Дубенського району Рівненської області) // Народознавчі зошити. 2014. № 4 (118). С. 721-725.

8. Стасюк А. Балади у записах Степана Івановича Турика // Тези науководослідницьких робіт переможців II етапу Всеукраїнського конкурсу-захисту науково-дослідницьких робіт учнів-членів Тернопільського обласного комунального територіального відділення МАН України. Тернопіль, 2016. С. 14.

9. Стасюк А. Побутові пісні у записах Степана Івановича Турика// Тези науководослідницьких робіт переможців II етапу Всеукраїнського конкурсу-захисту науково-дослідницьких робіт учнів-членів Тернопільського обласного комунального територіального відділення МАН України. Тернопіль, 2015. С. 26-28.

10. Чернихівський Г. Турик Степан Іванович// Тернопільський енциклопедичний словник : у 4 т. Т. 3 / редкол. : Г. Яворський та ін. Тернопіль: Видавничополіграфічний комбінат «Збруч», 2008. С. 477.

\section{References}

1. Archive materials from the collections of the Kremenets Museum of Local Lore (KKM), folklore group. It. 1-742 [in Ukrainian].

2. Dei, O., Yasenchuk, A. (Eds.). (1988). Ballads: Family-friendly relations. Kyiv: Naukova dumka [in Ukrainian]. 
3. Yakubchuk, M. (Ed.). (2001). Wedding in Dubenschyna: 170 Ukrainian wedding songs recorded by teacher-pensioner Turik Stepan Ivanovich. Kremenets [in Ukrainian].

4. Shubravska, M. (Ed.). (1982). Wedding songs. Vol. 1. Kyiv: Naukova dumka [in Ukrainian].

5. Shubravska, M. (Ed.). (1982). Wedding songs. Vol. 2. Kyiv: Naukova dumka [in Ukrainian].

6. Stelmashchuk, S., Medvedyk, P. (Eds.). (1989). Songs of Ternopil region: calendar ceremonies and family and home lyrics. Songbook. Vol. 1. Kyiv: Muzychna Ukrayina [in Ukrainian].

7. Smolyak, O. (2014). Ladkancas types of wedding songs of Southern Volhynia (on the material from the village Lipa of the Dubno district of the Rivne region). Narodoznavchi zoshyty, 4 (118), pp. 721-725 [in Ukrainian].

8. Stasyuk, A. (2016). Ballads in the records of Stepan Ivanovich Turyk. In: All-Ukrainian competition-defense of scientific-research works of students-members of Ternopil Branch of Junior Academy of Sciences of Ukraine. Ternopil, p. 14 [in Ukrainian].

9. Stasyuk, A. (2015). Household songs in the records of Stepan Ivanovich Turyk. In: AllUkrainian competition-defense of scientific-research works of students-members of Ternopil Branch of Junior Academy of Sciences of Ukraine. Ternopil, pp. 26-28 [in Ukrainian].

10. Chernihivskiy, G. (2008). Turik Stepan Ivanovich. Ternopilskiy entsiklopedichniy slovnik. Vol. 3. Ternopil: Publishing and printing company «Zbruch», p. 477 [in Ukrainian]. 